\title{
EFEKTIVITAS PENERAPAN MODEL PEMBELAJARAN NUMBERED HEADS TOGETHER (NHT) BERBANTUAN MEDIA PEMBELAJARAN QUESTION CARD DALAM MENINGKATKAN PEMAHAMAN KONSEP MATEMATIKA SISWA KELAS VIII SMPN 1 SANROBONE
}

\section{THE EFFECTIVENESS OF NUMBERED HEADS TOGETHER (NHT) LEARNING MODEL EQUIPPED WITH QUESTION CARD LEARNING MEDIA IN PROMOTING THE SEVENTH GRADERS' UNDERSTANDING OF MATHEMATICAL CONCEPTS IN SMPN 1 SANROBONE}

\author{
A. Sriyanti1), Ridwan Idris ${ }^{2),}$ Rikayanti Rahman ${ }^{3 \text { ) }}$ \\ 1,2,3)Fakultas Tarbiyah dan Keguruan Universitas Islam Negeri Alauddin Makassar \\ a.sriyanti@uin-alauddin.ac.i ${ }^{1}$, ridwan.idris@uin-alauddin.ac.id ${ }^{2}$, rikayanti@gmail.com³)
}

\begin{abstract}
Abstrak
Tujuan penelitian ini adalah melihat efektivitas model pembelajaran Numbered Heads Together (NHT) berbantuan media pembelajaran question card di kelas VIII SMPN 1 Sanrobone dalam meningkatkan pemahaman konsep matematika siswa di kelas VIII SMPN 1 Sanrobone. Jenis penelitian ini adalah eksperimen semu (Quasi Eksperimental) dengan non-equivalent control grup design. Sampel terdiri dari dua kelas yaitu kelas eksperimen menggunakan model pembelajaran Numbered Heads Together (NHT) berbantuan media pembelajaran question card dan kelas kontrol tidak dengan menggunakan model pembelajaran Numbered Heads Together (NHT) berbantuan media pembelajaran question card dengan teknik pengambilan sampel purposive sampling. Hasil uji hipotesis dengan taraf signifikan $\alpha=0,05$ menunjukkan bahwa nilai Sig (2-tailed) $>\alpha$ atau 0,093 $>0,05$ artinya tidak terdapat perbedaan rata-rata pemahaman konsep matematika siswa yang diajar menggunakan model pembelajaran Numbered Heads Together (NHT) berbantuan media pembelajaran question card dan kelas yang tidak diajar menggunakan model pembelajaran Numbered Heads Together (NHT) berbantuan media pembelajaran question card. Berdasarkan kesimpulan dapat diketahui bahwa penerapan model pembelajaran Numbered Heads Together (NHT) berbantuan media pembelajaran question card tidak efektif meningkatkan pemahaman konsep matematika siswa.
\end{abstract}

Kata Kunci: Numbered Heads Together (NHT), question cards, pemahaman konsep matematika

\begin{abstract}
This research aims to examine the effectiveness of Numbered Heads Together (NHT) learning model which is equipped with Question Card learning media in promoting seventh grader's understanding of mathematical concepts in SMPN 1 Sanrobone. In investigating the issue, this research used quasi experimental research with non-equivalent control group design. The research samples were selected using purposive sampling technique and were divided into two groups. The first group is an experimental class where Numbered Heads Together (NHT) learning model and Question Card learning media are implemented, while the second group is control class where Numbered Heads Together (NHT) learning model and Question Card learning media are not implemented. The results of hypothesis testing with significance rate of $\alpha=0,05$ shows that the value of Sig (2-tailed) $>\alpha$ atau $0.093>0.05$. This further indicates that there is no difference in students' understanding of mathematical concepts whether or not they are taught using Numbered Heads Together (NHT) learning model and Question Card learning media. Therefore, this research concludes that the implementation of
\end{abstract}


Numbered Heads Together (NHT) learning model and Question Card learning media is not effective in promoting seventh graders' understanding of mathematical concepts.

Key Words: Numbered Heads Together (NHT), question cards, mathematical concept understanding

How to Cite: Sriyanti, A., Idris, R., \& Rahman, R. (2019). Efektivitas penerapan model pembelajaran Numbered Heads Together (NHT) berbantuan media pembelajaran question card dalam meningkatkan pemahaman konsep matematika siswa kelas VIII SMPN 1 Sanrobone. Al-Asma: Journal of Islamic Education, 1(1), 18-28.

\section{PENDAHULUAN}

Pendidikan merupakan media yang sangat berperan dalam menciptakan manusia yang berkualitas dan berpotensi. Melalui pendidikan akan terjadi proses pendewasaan diri sehingga di dalam proses pengambilan keputusan terhadap suatu masalah yang dihadapi senantiasa disertai dengan rasa tanggung jawab yang besar (Annisa, Farahsanti, \& Veteran, 2016: 1-2). Salah satu bagian penting dari pendidikan adalah mata pelajaran dari substansi pendidikan formal itu sendiri. Pembelajaran matematika merupakan suatu ilmu universal yang dapat membantu perkembangan teknologi modern dan penting dalam berbagai disiplin ilmu. Matematika berada pada posisi sentral dalam dunia ilmu pengetahuan, karena seluruh cabang ilmu pengetahuan menggunakan ilmu matematika baik dari segi teori maupun dalam kehidupan sehari-hari (Budi Cahyono, 2016: 86). Belajar matematika bagi para peserta didik merupakan pembentukan pola pikir dalam pemahaman suatu materi maupun dalam suatu penalaran, atau suatu hubungan di antara materi matematika (Suherman, 2003: 57) Oleh karena itu, sangat diperlukan metode maupun strategi yang tepat dalam pembelajaran agar pemahaman dan hasil belajar matematika siswa meningkat. Guru hanya memfokuskan pembelajaran matematika lewat upaya penuangan pengetahuan matematika sebanyak mungkin. Kegiatan ini kurang mengaktifkan siswa, karena lebih berpusat kepada guru sehingga menyebabkan pemahaman peserta didik menjadi berkurang dan prestasi belajar siswa menurun.

Berdasarkan hasil survei yang dilakukan oleh Trends in International Mathematics and Science Study (TIMSS) tahun 2015, Indonesia berada pada urutan ke- 45 dari 50 negara dengan skor rata-rata 397 (K. P. dan Kebudayaan, 2016: 2). Sedangkan Survei Programme for International Student Assesment (PISA) pada tahun 2015, menyatakan bahwa prestasi matematika siswa Indonesia berada pada peringkat 63 dari 72 negara dengan skor rata-rata 386 (K. P. dan Kebudayaan, 2016: 1). Berdasarkan data survey tersebut dapat disimpulkan bahwa kondisi pembelajaran matematika belum memenuhi harapan salah satunya disebabkan oleh pemahaman konsep matematika peserta didik yang masih rendah.

Berdasarkan hasil observasi dengan salah satu guru di SMPN 1 Sanrobone, diketahui bahwa dalam mengajar guru mengunakan pembelajaran konvensional dan metode ceramah dikarenakan kemampuan peserta didik yang belum mampu mandiri dalam mengolah informasi sendiri namun masih harus dijelaskan secara detail. Selain itu, saat diberikan soal uraian yang sedikit berbeda dengan contoh sebelumnya, peserta didik merasa kesulitan untuk menyelesaikan bahkan lupa dengan penjelasannya. Terkadang peserta didik tidak mengetahui maksud dari soal atau tidak mengetahui setiap langkah 
penyelesaian soal tersebut. Sedangkan hasil wawancara dengan salah satu peserta didik, diketahui bahwa salah satu penyebab rendahnya pemahaman konsep adalah karena guru terkadang hanya meminta peserta didik untuk menulis materi yang dianggap penting dalam buku tersebut. Namun, guru terkadang tidak dapat menjelaskan semua yang peserta didik telah catat. Selain itu, peserta didik juga terkadang merasa bosan dalam mengikuti proses pembelajaran matematika. Dalam meningkatan keberhasilan belajar siswa, guru dapat menggunakan berbagai cara alternatif, salah satunya yaitu dengan menerapkan model pembelajaran kooperatif.

Pembelajaran kooperatif adalah model pembelajaran yang dirancang untuk membelajarkan kecakapan akademik (academic skill), sekaligus keterampilan sosial (social skill), termasuk interpersonal skill (Riyanto, 2012: 267). Sedangkan menurut Slavin (Riyadi \& Mosik, 2016: 2), pembelajaran kooperatif adalah suatu metode pembelajaran dimana siswa belajar dan bekerja dalam kelompok-kelompok kecil kolaboratif yang anggotanya 4-6 orang dengan struktur heterogen yang saling membantu satu sama lain dalam mempelajari materi pembelajaran. Salah satu model pembelajaran kooperatif yang biasa diterapkan di sekolah adalah model pembelajaran Numbered Heads Together (NHT).

Number Heads Together merupakan pembelajaran yang diawali dengan Numbering (Suprijono, 2012: 92). Menurut Miaz (2015: 2) Numbered Heads Together (NHT) adalah bagian dari model pembelajaran kooperatif yang menekankan pada struktur khusus yang dirancang untuk mempengaruhi pola interaksi siswa agar saling bekerja sama secara kooperatif. Selain itu, model ini juga dirancang untuk melibatkan lebih banyak siswa meninjau materi yang tercakup dalam pelajaran dan memeriksa pemahaman mereka tentang pelajaran tersebut. Untuk mempermudah pembentukan kelompok-kelompok dan perancangan tugas, teknik kepala bernomor ini bisa diterapkan pada kelompok-kelompok yang memang dibentuk secara permanen. Teknik kepala bernomor ini juga bisa digunakan untuk mengubah komposisi kelompok dengan lebih efisien. Pada saat-saat tertentu, siswa bisa diminta keluar dari kelompok yang biasanya dan bergabung dengan siswa-siswa lain yang bernomor sama dari kelompok lain. Cara ini bisa digunakan untuk mengurangi kebosanan/kejenuhan jika guru mengelompokkan siswa secara permanen (Huda, 2013: 139). Walaupun cara ini dapat mengurangi kejenuhan dalam belajar, akan tetapi dalam meningkatkan minat belajar, pemahaman konsep siswa serta hasil belajar yang baik maka guru dapat mengkolaborasikannya dengan media pembelajaran.

Media pembelajaran adalah alat yang digunakan sebagai perantara dalam menyampaikan pesan pembelajaran kepada peserta didik. Sebuah penelitian tentang pilihan media peserta didik dalam program hypermedia, hasilnya menyimpulkan bahwa $56 \%$ memilih media visual, $30 \%$ memilih teks, sementara $14 \%$ memilih media audio. Memilih pada hakikatnya adalah proses membuat keputusan dari berbagai alternatif pilihan yang sesuai dengan fungsinya masing-masing (Nwaocha, 2010: 108). Berdasarkan hasil penelitian tersebut, maka peneliti menggunakan media pembelajaran question card. Question card atau kartu soal merupakan media visual yang berupa kertas berukuran $10 \mathrm{x}$ $10 \mathrm{~cm}$. Isi dari kartu ini yaitu sebagian berisi soal-soal tentang materi yang akan diajarkan. Dengan media question card memungkinkan siswa belajar lebih rileks dengan memainkan kartu soal, di samping menumbuhkan tanggung jawab, kerjasama, persaingan sehat, dan keterlibatan belajar (Ardani, Putra, \& Kristiantari, 2014: 4). Selain itu, dengan 
menggunakan media pembelajaran maka konsep suatu materi akan lebih mudah dipahami oleh siswa.

Kemampuan pemahaman matematis adalah kemampuan menyerap dan memahami ide-ide matematika (Lestari \& Romdiani, 2018: 81). Pada pembelajaran di sekolah penguasaan konsep sangat diperlukan seorang siswa, karena konsep merupakan medium yang menghubungkan siswa dengan objek yang diketahui. Untuk dapat mengerti suatu materi pelajaran, seorang siswa harus terlebih dahulu mengenali dan mengerti konsep materi tersebut (Hamalik, 2005: 166). Indikator kemampuan pemahaman matematis menurut kementrian dan kebudayaan Indonesia sesuai kurikulum 2013 adalah sebagai berikut: a) Menyatakan ulang konsep yang telah dipelajari, yaitu mampu menjelaskan kembali konsep relasi dan fungsi dengan kalimat yang berbeda namun makna tetap sama. Misalnya, peserta didik mampu menuliskan kembali definisi relasi. b) Mengklasifikasikan objek-objek berdasarkan dipenuhi tidaknya persyaratan yang membentuk konsep tersebut, yaitu dapat menunjukkan fungsi sesuai dengan syarat-syarat yang dapat menyatakan sebagai relasi dan fungsi. Misalnya, peserta didik dapat memasangkan setiap anggota suatu himpunan dengan anggota himpunan yang lain sesuai aturan relasi yang ada. c) Mengidentifikasi sifat-sifat operasi atau konsep, yaitu kemampuan dalam menjelaskan sifat-sifat konsep relasi dan fungsi. Misalnya, peserta didik mampu menjelaskan sifat-sifat fungsi. d) Menerapkan konsep secara logis, yaitu kemampuan dalam menerapkan atau menggunakan rumus dengan benar. Misalnya, peserta didik mengetahui penggunaan cara eliminasi dan substitusi saat menentukan nilai a dan b dengan benar. e) Memberikan contoh dan bukan contoh dari konsep yang dipelajari, yaitu siswa mampu menunjukkan contoh dan bukan contoh dari relasi dan fungsi. Misalnya, peserta didik mampu memberikan contoh dan bukan contoh suatu fungsi. f) Menyajikan konsep dalam berbagai macam bentuk representasi matematis (tabel, grafik, diagram, gambar, sketsa, model matematika, atau cara lainnya) yaitu kemampuan dalam menerjemahkan soal kedalam bentuk lain. Misalnya, peserta didik mampu menyajikan contoh relasi dalam kehidupan sehari-hari kebentuk diagram panah, diagram Kartesius, dan himpunan pasangan berurutan. g) Mengaitkan berbagai konsep dalam matematika maupun diluar matematika, yaitu kemampuan mengaitkan konsep matematika yang lain dengan konsep fungsi. Misalnya dalam menentukan persamaan fungsi peserta didik mampu menyelesaikan setiap langkah penyelesaian, dimulai dari menentukan persamaan dari nilai yang diketahui hingga ke rumus atau persamaan fungsinya. h) Mengembangkan syarat perlu dan/atau syarat cukup suatu konsep, yaitu dapat mengembangkan syarat suatu konsep dalam menyelesaikan masalah. Misalnya, peserta didik mampu mengembangkan nilai yang diketahui untuk memperoleh nilai a dan b sebagai syarat untuk menentukan persamaan suatu fungsi (As'ari, 2017: 11).

Penerapan model pembelajaran NHT berbantuan media pembelajaran question card efektif meningkatkan pemahaman konsep matematika dengan adanya acuan yang mendasari atas penelitian yang sejenis. Berdasarkan penelitian sebelumnya, yaitu penelitian yang dilaksanakan oleh Sari (2015: 141) menyimpulkan bahwa model pembelajaran kooperatif tipe Numbered Heads Together berbantuan media pembelajaran efektif dalam meningkatkan pemahaman konsep peserta didik, hal ini ditunjukkan dengan peningkatan pemahaman konsep matematika peserta didik dengan model pembelajaran NHT lebih tingi dibandingkan dengan model pembelajaran langsung. Penelitian lain yang 
dilaksanakan oleh Qurniawati \& Annik (2013: 171) menyimpulkan bahwa model pembelajaran kooperatif tipe Numbered Heads Together (NHT) dengan media kartu pintar dan kartu soal efektif dalam meningkatkan prestasi belajar siswa.

Berdasarkan uraian di atas, peneliti merasa perlu menerapkan model pembelajaran kooperatif tipe Numbered Heads Together (NHT) berbantuan media pembelajaran question card untuk meningkatkan pemahaman konsep matematika siswa kelas VIII SMPN 1 Sanrobone.

\section{METODE PENELITIAN}

Penelitian ini adalah penelitian eksperimen dengan jenis penelitian eksperimen semu (Quasi eksperimental) dan desain penelitian Nonequivalent Control Group Design. Desain ini terdapat dua kelompok eksperimen yang diberi perlakuan. Kelompok eksperimen adalah kelompok yang diajar menggunakan model pembelajaran Numbered Heads Together (NHT) berbantuan media pembelajaran question card dan kelompok kontrol adalah kelompok yang tidak diajar menggunakan model pembelajaran Numbered Heads Together (NHT) berbantuan media pembelajaran question card. Dua kelompok tersebut diberikan pretest kemudian diberi perlakuan dan terakhir diberikan posttest.

Penelitian ini akan dilaksanakan di SMP Negeri 1 Sanrobone, Kabupaten Takalar, Provinsi Sulawesi Selatan. populasi dalam penelitian ini adalah seluruh siswa kelas VIII SMP Negeri 1 Sanrobone tahun ajaran 2018/2019. Pada penelitian ini peneliti menggunakan teknik penentuan sampel dengan pertimbangan tertentu. Berdasarkan hasil uji coba dan wawancara di sekolah tersebut, maka pengambilan sampel dipilih dengan beberapa pertimbangan yaitu: sampel dipilih karena hasil uji coba menunjukkan kemampuan akademik kedua kelas tersebut relatif sama, dan kedua kelas tersebut juga mendapatkan fasilitas kelas yang sama. Berdasarkan pertimbangan tersebut, maka kelas VIII B dan kelas VIII C dipilih sebagai sampel oleh peneliti. Dalam penelitian ini, kelas VIII B sebagai kelas Eksperimen dan kelas VIII C sebagai kelas kontrol.

Pengumpulan data pada penelitian ini dilakukan dengan observasi dan test. Lembar observasi terdiri atas dua yaitu lembar observasi keterlaksanaan model pembelajaran Numbered Heads Together (NHT) dan lembar observasi aktivitas siswa selama proses pembelajaran berlangsung. Pada penelitian ini, dilakukan dua kali tes untuk setiap kelas, yaitu pretest dan posttest. Pretest digunakan untuk melihat hasil belajar matematika siswa sebelum diberikan perlakuan dan posttest digunakan untuk melihat hasil belajar matematika siswa setelah diberikan perlakuan.

Pengolahan data hasil penelitian digunakan dua teknik analisis statistik yaitu statistik deskriptif dan statistik inferensial. Analisis deskriptif digunakan untuk melihat gambaran secara umum hasil penelitian. Analisis statistik inferensial digunakan untuk menguji hipótesis penelitian menggunakan uji indpendent simple t-test dengan syarat data tersebut berdistribusi normal dan homogen sehingga terlebih dahulu dilakukan uji normalitas dan uji homogenitas. 


\section{HASIL PENELITIAN DAN PEMBAHASAN}

Berikut ini adalah tabel hasil analisis deskriptif data hasil belajar matematika kelas eksperimen yaitu kelompok yang diajar dengan menggunakan model pembelajaran kooperatif tipe Numbered Heads Together (NHT) berbantuan media pembelajaran question card pada siswa kelas VIII B.

Tabel 1. Nilai Hasil Pretest dan Posttest pada Kelas Eksperimen

\begin{tabular}{|c|c|c|c|c|c|}
\hline & $\mathbf{N}$ & Minimum & Maximum & Mean & Std. Deviation \\
\hline $\begin{array}{l}\text { Pretest } \\
\text { Eksperimen }\end{array}$ & 27 & 10 & 62 & 27.11 & 11.784 \\
\hline $\begin{array}{l}\text { Posttest } \\
\text { Eksperimen }\end{array}$ & 27 & 28 & 82 & 55.74 & 17.801 \\
\hline $\begin{array}{ll}\text { Valid } & \mathrm{N} \\
\text { (Listwise) } & \end{array}$ & 27 & & & & \\
\hline
\end{tabular}

Berdasarkan tabel diatas dengan melihat nilai pretest dan posttest pada kelas yang diajar menggunakan model pembelajaran kooperatif tipe Numbered Heads Together (NHT) berbantuan media pembelajaran question card dapat meningkatkan pemahaman konsep matematika siswa kelas VIII SMPN 1 Sanrobone. Berikut adalah kategorisasi nilai pemahaman konsep matematika siswa kelas eksperimen sebelum dan setelah diberikan perlakuan.

Tabel 2. Kategori Nilai Pemahaman Konsep Matematika Siswa Pretest dan Posttest pada Kelas Eksperimen

\begin{tabular}{ccccccc}
\hline No & $\begin{array}{c}\text { Rentang } \\
\text { Nilai }\end{array}$ & \multicolumn{2}{c}{ Pretest } & \multicolumn{2}{c}{ Posttest } & Kategori \\
\cline { 3 - 6 } & Frekuensi & $\begin{array}{c}\text { Persentase } \\
\text { (\%) }\end{array}$ & Frekuensi & $\begin{array}{c}\text { Persentase } \\
\text { (\%) }\end{array}$ & \\
\hline 1 & $0-20$ & 10 & 37 & 0 & 0 & $\begin{array}{c}\text { Sangat } \\
\text { Rendah }\end{array}$ \\
\hline 2 & $21-40$ & 15 & 55 & 7 & 26 & Rendah \\
\hline 3 & $41-60$ & 1 & 4 & 10 & 37 & Sedang \\
\hline 4 & $61-80$ & 1 & 4 & 9 & 33 & Tinggi \\
\hline 5 & $81-100$ & 0 & 0 & 1 & 4 & $\begin{array}{c}\text { Sangat } \\
\text { Tinggi }\end{array}$ \\
\hline \multicolumn{2}{c}{ Jumlah } & 27 & 100 & 27 & 100 & \\
\hline
\end{tabular}

Berdasarkan tabel diatas diperoleh hasil bahwa sebelum diberi perlakuan ratarata hasil belajar siswa berada pada kategori rendah dan setelah diberi perlakuan berada pada kategori sedang.

Berikut ini adalah tabel hasil analisis deskriptif data hasil belajar matematika kelas kontrol yaitu kelompok yang tidak diajar menggunakan model pembelajaran kooperatif tipe Numbered Heads Together (NHT) berbantuan media pembelajaran question card pada siswa kelas VIII C SMPN 1 Sanrobone. 
Tabel 3. Nilai Hasil Pretest dan Posttest pada Kelas Kontrol

\begin{tabular}{cccccc}
\hline & N & Minimum & Maximum & Mean & Std. Deviation \\
\hline $\begin{array}{c}\text { Pretest Kelas } \\
\text { Kontrol }\end{array}$ & 27 & 13 & 64 & 37.30 & 13.660 \\
\hline $\begin{array}{c}\text { Posttest Kelas } \\
\text { Kontrol }\end{array}$ & 27 & 22 & 77 & 48.07 & 14.995 \\
\hline $\begin{array}{c}\text { Valid N } \\
\text { (Listwise) }\end{array}$ & 27 & & & & \\
\hline
\end{tabular}

Berdasarkan tabel diatas dengan melihat nilai pretest dan posttest pada kelas yang tidak diajar menggunakan model pembelajaran kooperatif tipe NHT dengan media question card juga mampu meningkatkan pemahaman konsep matematika siswa kelas VIII SMPN 1 Sanrobone. Berikut adalah kategorisasi nilai pemahaman konsep matematika siswa kelas kontrol sebelum dan setelah diberikan perlakuan.

Tabel 4. Kategori Nilai Pemahaman Konsep Matematika Siswa Pretest dan Posttest pada

\begin{tabular}{ccccccc} 
No & Rentang & \multicolumn{2}{c}{ Pretest } & \multicolumn{2}{c}{ Posttest } & Kategori \\
\cline { 3 - 6 } & Nilai & Frekuensi & $\begin{array}{c}\text { Persentase } \\
\text { (\%) }\end{array}$ & Frekuensi & $\begin{array}{c}\text { Persentase } \\
\text { (\%) }\end{array}$ & \\
\hline 1 & $0-20$ & 3 & 11 & 0 & 0 & Sangat Rendah \\
\hline 2 & $21-40$ & 14 & 52 & 10 & 37 & Rendah \\
\hline 3 & $41-60$ & 7 & 26 & 10 & 37 & Sedang \\
\hline 4 & $61-80$ & 3 & 11 & 7 & 26 & Tinggi \\
\hline 5 & $81-100$ & 0 & 0 & 0 & 0 & Sangat Tinggi \\
\hline \multicolumn{2}{l}{ Jumlah } & 27 & 100 & 27 & 100 & \\
\hline
\end{tabular}

Berdasarkan tabel diatas diperoleh hasil bahwa sebelum diberi perlakuan ratarata pemahaman konsep matematika siswa berada pada kategori rendah dan setelah diberi perlakuan berada pada kategori rendah dan sedang namun sudah terdapat 7 orang siswa berada pada kategori tinggi. Berikut ini adalah tabel hasil analasis data hasil belajar matematika kelas kontrol dan kelas eksperimen.

Tabel 5. Hasil Uji Independent Sample T- Test Posttest Pemahaman Konsep Matematika Siswa Kelas Eksperimen dan Siswa Kelas Kontrol

\section{Levene's Test for \\ Equality or \\ Hest for Equality of Means}

Variances

\begin{tabular}{lcccccc}
\hline $\begin{array}{l}\text { Posttest } \\
\begin{array}{l}\text { Equal variances } \\
\text { assumed }\end{array}\end{array}$ & $\mathrm{f}$ & Sig. & $\mathrm{T}$ & $\mathrm{Df}$ & $\begin{array}{c}\text { Sig. }(2- \\
\text { tailed })\end{array}$ & $\begin{array}{c}\text { Mean } \\
\text { Difference }\end{array}$ \\
\cline { 2 - 7 } & & & 1.712 & 52 & .093 & 7.667 \\
\cline { 5 - 7 } $\begin{array}{l}\text { Equal variances } \\
\text { not assumed }\end{array}$ & 1.997 & .174 & 1.712 & 50.541 & .093 & 7.667 \\
\hline
\end{tabular}


Berdasarkan tabel diatas diperoleh bahwa tidak terdapat perbedaan pemahaman konsep matematika antara kelas yang tidak diajar menggunakan model pembelajaran NHT berbantuan media pembelajaran question card dengan kelas yang diajar menggunakan model pembelajaran NHT berbantuan media pembelajaran question card. Karena tidak terdapat perbedaan antara kelas eksperimen dan kelas kontrol, maka telah dapat diketahui bahwa penerapan model pembelajaran NHT berbantuan media pembelajaran question card tidak efektif dalam meningkatkan pemahaman konsep matematika kelas VIII SMPN 1 Sanrobone. Melalui uji statistik deskriptif diperoleh hasil bahwa penerapan model pembelajaran NHT berbantuan media pembelajaran question card diperoleh rata-rata hasil belajar matematika nilai posttest yaitu 55,74 dan berada pada kategori sedang dengan besar kenaikan nilai rata-rata yaitu 37\% sedangkan pada kelas yang tidak diajar menggunakan model pembelajaran NHT berbantuan media pembelajaran question card diperoleh rata-rata hasil belajar matematika posttest yaitu 48,07 dengan presentase sebesar $88 \%$.

Uji statistik inferensial dilakukan untuk menguji hipotesis penelitian. Berdasarkan uji prasyarat statistik inferensial data yang diperoleh berdistribusi normal dan homogen. Uji statistik inferensial yang digunakan adalah uji independent sample t-test. Berdasarkan uji hipotesis yang telah dilakukan dengan derajat signifikan 0,05 diperoleh nilai sig $<\alpha$ yaitu 0,093 $>0,05$ yang berarti bahwa tidak terdapat perbedaan rata-rata pemahaman konsep matematika siswa yang diajar menggunakan model pembelajaran kooperatif tipe Numbered Heads Together (NHT) berbantuan media pembelajaran question card dan tidak diajar menggunakan model pembelajaran kooperatif tipe Numbered Heads Together (NHT) berbantuan media pembelajaran question card dalam meningkatkan pemahaman konsep matematika siswa kelas VIII SMPN 1 Sanrobone. Dari hasil uji independent sample t-test telah dapat diketahui bahwa model pembelajaran NHT berbantuan media pembelajaran question card tidak efektif dalam meningkatkan pemahaman konsep matematika siswa.

Keterlaksanaan model pembelajaran NHT berbantuan media pembelajaran question card dapat dilihat melalui lembar observasi siswa. Berdasarkan lembar observasi siswa pada kelas yang diajar menggunakan model pembelajaran NHT berbantuan media pembelajaran question card dari 27 siswa terdapat 14 siswa (52\%) yang melaksanakan kegiatan pembelajaran keseluruhan sedangkan kelas yang tidak diajar menggunakan model pembelajaran NHT berbantuan media pembelajaran question card dari 27 siswa terdapat 11 orang (41\%). Hal ini menunjukkan keterlaksanaan model pembelajaran NHT berbantuan media question card lebih baik jika dibandingkan dengan kelas yang tidak diajar menggunakan model pembelajaran NHT berbantuan media question card. Hasil penelitian ini sejalan dengan Nurwati \& Zamsir (2014: 135) dalam penelitian yang sejenis menyimpulkan bahwa tidak terdapat perbedaan yang signifikan antara rerata hasil belajar matematika siswa yang diajar dengan model pembelajaran kooperatif tipe TSTS dan siswa yang diajar dengan model pembelajaran kooperatif tipe NHT.

Keterlaksanaan pembelajaran sesuai dengan lembar observasi pada setiap kelas dipengaruhi oleh situasi kelas, karakteristik siswa dan perlakuan yang diberikan berbeda pada setiap kelas. Ketidakefektifan pembelajaran pada kelas VIII B sebagai kelas eksperimen salah satu penyebabnya karena kelas VIII B lebih sulit untuk dikoordinir jika dibandingkan dengan kelas VIII C. Selain itu, terdapat peserta didik dikelas VIII B yang merasa kurang cocok dengan teman kelompoknya, kelompok yang dianggap heterogen 
ternyata belum benar-benar heterogen, dan peserta didik juga kesulitan dalam mengerjakan LKPD. Hal ini sesuai dengan pendapat Sagala (Oktariani, 2018: 26) bahwa kelemahan dalam bekerja kelompok adalah a) sulit untuk membuat kelompok yang homogen, baik intelegensi, bakat dan minat, atau daerah tempat tinggal; b) siswa yang oleh guru telah dianggap homogen, sering tidak merasa cocok dengan anggota kelompoknya. Selain mereka merasa kurang cocok dalam kelompok, pengelompokan peserta didik yang telah dianggap heterogen ternyata belum benar-benar heterogen sehingga menghambat proses pembelajaran khususnya saat diskusi berlangsung. Dan kesalahan peneliti juga tidak mengubah kembali komposisi kelompok selama beberapa kali pertemuan. Peserta didik pada kelas eksperimen mengalami kesulitan dalam mengerjakan LKPD yang telah peneliti siapkan diakibatkan karena peserta didik belum terbiasa dalam mengerjakan LKPD sehingga mereka senantiasa bertanya yang mengakibatkan suasana kelas menjadi ribut. walaupun dengan adanya LKPD ini juga salah satu penyebab peserta didik menjadi lebih aktif dalam proses pembelajaran. Selain itu, peneliti juga menemukan kendala berupa keterbatasan waktu sehingga proses pembelajaran tidak efektif yang berdampak pada pemahaman konsep dan hasil belajar peserta didik. Hal ini sesuai dengan kekurangan NHT yang telah dikemukakan oleh Shoimin (Lince, 2016: 209) bahwa NHT tidak cocok diterapkan pada jumlah siswa yang banyak karena membutuhkan waktu yang banyak, dan karena adanya keterbatasan waktu maka tidak semua anggota kelompok dapat dipanggil oleh peneliti untuk mengerjakan soal pada question card di depan kelas. Tidak hanya itu, hasil penelitian ini juga sangat dipengaruhi oleh cara mengajar peneliti yang belum dapat dikatakan memiliki teknik dan kontrol kelas yang baik. Peneliti juga kurang terampil dalam menciptakan suasana kelas yang menyenangkan sehingga saat fokus belajar peserta didik telah hilang, peneliti kesulitan untuk mengembalikan fokus belajar peserta didik.

\section{SIMPULAN}

Pemahaman konsep matematika yang diajar menggunakan model pembelajaran NHT berbantuan media pembelajaran question card mampu meningkatkan pemahaman konsep matematika siswa dengan nilai rata-rata pretest yaitu 27,11 (kategori rendah) dan nilai posttest yaitu 55,74 (kategori sedang) dengan besar peningkatan 37\%. Pemahaman konsep matematika siswa yang tidak diajar menggunakan model pembelajaran NHT berbantuan media pembelajaran question card mampu meningkatkan pemahaman konsep matematika siswa dengan nilai rata-rata pretest yaitu 37,30 (kategori rendah) dan nilai posttest yaitu 48,07 (kategori sedang) dengan besar peningkatan 37\%. Berdasarkan hasil analisis statistik inferensial diperoleh bahwa 0,093 $>0,05$ artinya bahwa tidak terdapat perbedaan pemahaman konsep matematika antara kelas eksperimen dan kelas kontrol, sehingga dapat diketahui bahwa penerapan model pembelajaran Number Head Together (NHT) berbantuan media pembelajaran question card tidak efektif dalam meningkatkan pemahaman konsep matematika. 


\section{DAFTAR PUSTAKA}

Annisa, P. E., Farahsanti, I., \& Veteran. (2016). Implementasi Model Pembelajaran Numbered Heads Together (NHT) untuk Meningkatkan Pemahaman dan Minat Belajar Mahasiswa. Jurnal Pendidikan dan Pembelajaran Matematika, 2(2), 1-13. Retrieved from https://digilib.uns.ac.id.

Ardani, N. P. M., Putra, I. K. A., \& Kristiantari, M. G. R. (2014). Pengaruh Model Kooperatif TGT Berbantuan Media Question Card terhadap Hasil Belajar IPS Siswa Kelas V. Jurnal Mimbar PGSD Universitas Pendidikan Ganesha, 2(1),1-11. Retrieved from https://ejournal.undiksha.ac.id/index.php/ijpgsd/article/view/2275/1970.

As'ari, A. R. dan M. T. dan E. V. dan Z. I. dan I. T. (2017). Matematika. Jakarta: Kementrian Pendidikan dan Kebudayaan.

Cahyono, B. N. A. (2016). Analisis Soal Dalam Buku Siswa Matematika Kurikulum 2013 Kelas. Jurnal Review Pembelajaran Matematika, 1(1), 86-98. Retrieved from https://jurnalftk.uinsby.ac.id.

Hamalik, O. (2005). Perencanaan Pengajaran Pendekatan Sistem. Jakarta: Bumi Aksara.

Huda, M. (2013). Cooperative Learning. Yogyakarta: Pustaka Belajar.

Kebudayaan, K. P. dan. (2016a). Hasil PISA 2015. Retrieved from https://www.researchgate.net/publication/322420745 hasil PISA Indonesia tah un 2015 mengalami peningkatan.

Kebudayaan, K. P. dan. (2016b). Hasil TIMSS 2015. Retrieved from https://puspendik.kemdikbud.go.id/seminar/upload/hasil Seminar puspendik.

Lestari, P., \& Romdiani, N. S. (2018). Efektivitas Pembelajaran dengan Media Kartu untuk Meningkatkan Kemampuan Pemahaman Matematis Siswa. Jurnal Nasional Pendidikan Matematika (JNPM), 3(1), 17-24. Retrieved from https://www.researchgate.net.

Lince, R. (2016). Creative Thinking Ability to Increase Student Mathematical of Junior High School by Applying Models Numbered Heads Together. Journal of Education and Practice, 7(6), 206-212. Retrieved from http://files.eric.ed.gov.

Miaz, Y. (2015). The Implementation Of Numbered Heads Together To Improve The Students'Achievement Of Social Sciences In Primary School. Research Journal of Social Sciences, 10, 40-45. Retrieved from http://www.aensiweb.net/AENSIWEB/rjss/rjss/2015/November\%20December/40-45.pdf

Nurwati, \& Zamsir. (2014). Efektivitas Model Pembelajaran Kooperatif Tipe Two Stay Two Stray dan Numbered Heads Together terhadap Hasil Belajar Matematika Siswa Kelas VIII SMP Negeri 10 Kendari. Jurnal Penelitian Pendidikan Matematika, 2(3), 1-16. Retrieved from https://ojs.uho.ac.id

Nwaocha, V. O. (2010). Enhancing students interest in mathematics via multimedia presentation. African Jurnal of Mathematics and Computer Science Research, 3(7), 107-113. https://doi.org/10.1103/PhysRevA.74.023615.

Oktariani. (2018). Perbandingan Hasil Belajar Sistem Koloid dengan Menerapkan Model Pembelajaran Kooperatif Tipe Numbered Head Together (NHT) dan Team Games Tournament (TGT) di SMA. Jurnal Pendidikan Kimia (Orbital), 2(1), 22-27. Retrieved from https://www.researchgate.net.

Qurniawati, Annik, D. (2013). Efektivitas Metode Pembelajaran Kooperatif Tipe Numbered 
Heads Together (NHT) dengan Media Kartu Pintar dan Kartu Soal terhadap Prestasi Belajar Siswa pada Materi Genap SMA Negeri 8 Surakarta Tahun Pelajaran 2012/2013. Jurnal Pendidikan Kimia (JPK), 2(3), 166-174. Retrieved from http://jurnal.fkip.uns.ac.id/index.php/kimia/article/view/2654/1869

Riyadi, A. S., \& Mosik. (2016). Penerapan Metode Pembelajaran Kooperatif Tipe Nht Untuk Meningkatkan Pemahaman Konsep Dan Komunikasi Ilmiah. UPEJ Unnes Physics Education Journal, 3(2), 2-8. Retrieved from https://journal.unnes.ac.id/sju/index.php/upej/article/view/3590

Riyanto, Y. (2012). Paradigma Baru Pembelajaran. Jakarta: Prenada Media Group.

Sari, Y. M., \& Kurniasih, N. (2015). Efektivitas Numbered Heads Together Berbantu Media Kartu terhadap Siswa. Jurnal Pendidikan Surya Edukasi, 139-142. Retrieved from http://ejournal.umpwr.ac.id/index.php/ekuivalen/article/view/2720

Suherman, E. (2003). Strategi Pembelajaran Matematika. (E. Suherman, Ed.). Bandung: UPI.

Suprijono, A. (2012). Cooperative Learning. Yogyakarta: Celeban Timur. 